\title{
IMPLEMENTASI PENGELOLAAN DANA ZAKAT PADA BANK UMUM SYARIAH DI INDONESIA
}

\author{
Nurnasrina $^{1}$; P. Adiyes Putra ${ }^{2}$ \\ ${ }^{1}$ Universitas Islam Negeri Sultan Syarif Kasim Riau \\ Jl. HR. Soebrantas No. 155 KM 15 Panam - Pekanbaru \\ E-mail : nurnasrina@uin-suska.ac.id
}

diterima: 20/7/2020; direvisi: 18/8/2020; diterbitkan: 26/3/2021

\begin{abstract}
This study aims to determine the implementation of the management of zakat funds at Islamic Commercial Banks (BUS) in Indonesia and to find out the supporting and inhibiting factors in managing zakat funds at BUS in Indonesia. The type of data is secondary data, the population of 14 BUS using descriptive analysis. The results showed that of 14 BUS in Indonesia, only 10 BUS managed zakat funds. Management of zakat funds on 10 BUS uses 4 models. Zakat funds are distributed in the fields of economic empowerment, education, health, dakwah and social activities. Supporting factors for the management of zakat funds on BUS are financial technology, office networks totaling 1,942 units, compulsory zakat policies for employees who reach nisab, and customer awareness for zakat. The inhibiting factors in the management of zakat funds on BUS in Indonesia are from the legal aspects, namely: (1) Article 4 paragraph 2 of Law (Law) No. 21 of 2008 related to the social role of sharia banking which is optional, (2) Explanation of article 7 paragraph 2 of Law no. 23 of 2011 concerning the management of zakat which does not include Islamic banking as a partner of BAZNAS in managing zakat, and (3) Amanah article 15b of Law no. 25 of 2007 concerning corporate social responsibility obligations so that Islamic banks prioritize corporate social responsibility obligations.
\end{abstract}

Keywords: Zakat, Islamic Banking, BAZNAS and Law

\section{PENDAHULUAN}

Legalitas operasional perbankan syariah pada awalnya berdasarkan pasal $6 \mathrm{~m}$ pada Undang-Undang (UU) Nomor 7 tahun 1992 tentang perbankan yang menyebutkan bahwa kegiatan usaha bank boleh berdasarkan bunga atau bagi hasil, kata "bagi hasil" merupakan dasar operasional bank berdasarkan prinsip syariah tanpa bunga. Kemudian UU No.7 Tahun 1992 di ganti dengan UU No.10 Tahun 1998 yang berisi lebih spesifik tentang bank syariah namun aturan-aturan di dalamnya masih gabungan antara bank konvensional dan bank syariah (Kasmir, 2016). Pada tahun 2008 disahkannya UU khusus yaitu UU No. 21 Tahun 2008 tentang perbankan syariah. Pengesahan UU ini memberi manfaat pada semakin kuatnya dasar hukum operasional perbankan syariah serta turut mendukung percepatan tumbuh kembang perbankan syariah di Indonesia.

Perkembangan perbankan syariah sejak tahun 1992 hingga April 2020, sangat menggembirakan, secara perlahan dari jumlah dan asset bank syariah semakin bertambah. Berdasarkan data statistik Perbankan Syariah sampai April 2020 menunjukkan bahwa Bank Umum Syariah (BUS) telah berjumlah 14 dengan total asset Rp. 348,29 Triliyun, dan Unit Usaha Syariah (UUS) 20 unit dengan asset Rp. 172,93 Triliyun. Total keseluruhan asset BUS dan UUS telah mencapai Rp. 521,23 Triliyun dengan market share $6.01 \%$ dari total asset perbankan Indonesia, jumlah ini belum termasuk dari 164 Bank Pembiayaan Rakyat Syariah (BPRS). Dan jaringan kantor se-Indonesia yang mencapai jumlah 2.331 unit (Otoritas Jasa Keuangan (OJK), 2020). 
Jurnal Ilmiah Ekonomi dan Bisnís

Vol. 18. No.1, Maret 2021 : 1-9

EISSN : $2442-9813$

ISSN : $1829-9822$

UU No. 21 Tahun 2008 tentang perbankan syariah pasal 4 ayat 2 mengamanahkan penambahan fungsi sosial yaitu "bank syariah dan Unit Usaha Syariah (UUS) "dapat" menjalankan fungsi sosial dalam bentuk lembaga baitul mal, yaitu menerima dana yang berasal dari zakat, infak, sedekah, hibah dan dana sosial lainnya kemudian menyalurkannya kepada organisasi pengelola zakat (Nurnasrina dan P. adiyes Putra, 2018). Kata "dapat" pada Pasal 4 ayat 2 ini memberi kesan bahwa tugas perbankan syariah dalam mengelola zakat bersifat fasif, fakultatif dan sukarela (Ahmad Dakhoir, 2015). Kata "dapat" juga dalam bentuk pilihan, yaitu perbankan syariah dapat menjalankan fungsi sosial atau mengabaikannya, pilihan ini berdampak pada terjadinya permasalahan dalam pelaksanaan pengelolaan dana zakat di bank syariah.

Permasalahan yang dapat ditimbulkan terkait penerapan fungsi sosial tersebut yaitu pengelolaan dana zakat belum terlaksana secara transparan dan akuntabel. Beberapa bank syariah bahkan mencampur-adukkan antara dana zakat dengan dana Corporate Social Responsibility (CSR), hasil penelitian menunjukkan bahwa sumber dana CSR yang terdapat pada bank syariah berasal dari dana zakat, infak dan sedekah serta sumber dana qordh (denda dan pendapatan non halal) sehingga terdapat pencampuradukan antara dana CSR dengan dana zakat (Astrid Maharani, 2016). Permasalahan lain pada dana zakat dan dana CSR adalah distribusi dana belum pada sektor rill dan masyarakat belum merasakan jika perbankan syariah memiliki tanggung jawab sosial, Oleh karena itu, perbaikan, evaluasi, dan inovasi perlu terus dilakukan guna meningkatkan kepercayaan nasabah Serta membuktikan bahwasanya perbankan syariah tidak hanya memiliki business oriented tetapi juga social responsibility (Nikmatul Masruroh, 2015).

Indah Purbasari menjelaskan bahwa dalam prakteknya bank syariah lebih mempublikasikan dana tanggung jawab sosial perusahaan, meskipun di dalamnya terdapat dana zakat. Permasalahan ini dipicu oleh dua tanggung jawab yang harus dilaksanakan oleh perbankan syariah, yaitu sebagai perusahaan yang harus tunduk dengan Undang-Undang Nomor 40 tahun 2007 tentang Perseroan Terbatas (PT) dan Undang-Undang Nomor 25 tahun 2007 tentang Penanaman Modal yang mengatur kewajiban PT mengalokasikan dana tanggung jawab sosial perusahaan/CSR Disisi lain perbankan syariah juga diamanahkan untuk mengumpulkan dana zakat perusahaan dan karyawan sesuai dengan UU No. 21 Tahun 2008 tentang Perbankan Syariah (Indah Purbasari, dkk, 2015)

Fungsi sosial perbankan syariah memiliki peran yang stategis dan dapat menjadi salah satu alternatif model dalam upaya meningkatkan penghimpunan dan penyaluran dana zakat. Namun alternatif pengelolaan yang ada pada perbankan syariah belum di akui secara ekplisit dalam UU No. 23 Tahun 2011 tentang pengelolaan zakat. Belum tegasnya pengaturan bank syariah menjalankan fungsi sosial untuk mengelola zakat dalam UU pengelolaan zakat mendatangkan kekaburan fungsi perbankan syariah menjalankan fungsi sosial. Kekaburan fungsi ini menyebabkan terjadinya problem yuridis.

Problem yuridis dapat dilihat berdasarkan ketentuan Pasal 7 ayat 2 pada UU No. 23 Tahun 2011 tentang pengelolaan zakat, yang menyebutkan bahwa "dalam melaksanakan tugas dan fungsinya, Badan Amil Zakat Nasional (BAZNAS) dapat bekerja sama dengan pihak terkait sesuai dengan ketentuan peraturan perundang-undangan (PPID BAZNAS, 2020). Dalam penjelasan Pasal 
7 ini peran perbankan syariah sebagai lembaga penghimpun zakat belum disebutkan secara kongkrit. Masalah ini menimbulkan berbagai masalah normatif dalam regulasi pengelolaan zakat pada perbankan syariah di Indonesia (Aristoni, 2018).

Problematika di atas menyebabkan perbankan syariah khususnya Bank Umum Syariah (BUS) mengalami ketidakpastian hukum dalam menjalankan fungsi sosialnya dan kurang bersemangat dalam mengelola dana zakat karena bersifat fasif, fakultatif dan sukarela. Berdasarkan kondisi tersebut, maka rumusan masalah pada penelitian ini adalah bagaimana implementasi pengelolaan dana zakat pada BUS di Indonesia dan Apa faktor pendukung dan penghambat pengelolaan dana zakat pada BUS di Indonesia dengan tujuan untuk mengetahui secara rinci tentang implementasi pengelolaan dana zakat pada BUS di Indonesia dan mengetahui faktor pendukung dan penghambat pengelolaan dana zakat pada BUS.

\section{TINJAUAN PUSTAKA}

Pengelolaan berasal dari kata "kelola" yang bermakna mengendalikan, menyelenggarakan atau mengurus. Kemudian mendapat imbuhan "pe dan an" menjadi "pengelolaan" bermakna proses melakukan kegiatan tertentu dengan menggerakkan tenaga orang lain (KKBI Online: 2020). Menurut pasal 1 ayat 1 UU No. 23 Tahun 2011 tentang pengelolaan zakat: pengelolaan zakat adalah kegiatan perencanaan, pelaksanaan, dan pengoordinasian dalam pengumpulan, pendistribusian dan pendayagunaan zakat (PPID BAZNAS, 2019).

Kata zakat (al-zakah) penyebutannya dalam Al-Qur'an diulang sebanyak 32 kali dalam 19 surat dan 32 ayat. Kata dasar zakat berasal dari alzakah, al-ziyadah yang berarti tumbuh, tambah, bergerak dan berkembang (Yusuf Qardhawi, 1996). Disamping itu al-zakah juga bermakna bersih (al-zakiyyah), suci (al-thaharoh), berkah (al-barkah), baik atau layak (al-shalah), dan terpuji (almad-hu) (Ibnu Qudamah al-Maqdisi, 2019). Pemaknaan zakat dengan istilah di atas berarti bahwa setiap harta yang telah dikeluarkan zakatnya akan menjadi suci, bersih, berkah, baik, tumbuh dan berkembang. Istilah ini juga disifatkan kepada jiwa orang yang mengeluarkan zakat, dimana orang yang mengeluarkan zakat hatinya menjadi suci, bersih, selalu mendapatkan keberkahan dan menumbuhkan pahalanya (Muhammad Ridwan dan Mas'ud, 2005).

Berdasarkan pasal 1 ayat 1 UU No. 23 Tahun 2011 menyebutkan zakat adalah harta yang wajib dikeluarkan oleh seorang muslim atau badan usaha untuk diberikan kepada yang berhak menerimanya sesuai dengan syariat Islam (PPID BAZNAS, 2019). Menurut Asy-Syaukani, zakat adalah pemberian sebagian harta yang telah mencapai nishab kepada orang fakir dan sebagainya dan tidak mempunyai sifat yang dapat dicegah syara' untuk mentasharufkan kepadanya (Teuku Muhammad Hasby Ash-Shiddiqy, 2009). Menurut Yusuf Qardhawi, zakat adalah sebutan atau nama untuk bagian yang sudah ditentukan dari harta seseorang yang diwajibkan Allah SWT untuk dibagikan kepada para mustahik (Yusuf Qardhawi, 1997).

Defenisi zakat yang dikemukakan oleh 4 imam mazhab (Malikiah, Hanafiyah, Syafiiah, dan Hanabillah) sebagai berikut; (a) Ulama Malikiah menyatakan zakat adalah mengeluarkan bagian tertentu dari jenis-jenis harta tertentu yang sudah mencapai nisab untuk mustahik manakal telah sempurna kepemilikannya dan telah mencapai haul (satu tahun penuh) diluar harta pertambangan dan pertanian. (b) Ulama Hanafiyah mendefenisikan zakat dengan pengalihan kepemilikan dari sebagian 


\section{Jurnal Ilmiah Ekonomi dan Bisnis}

Vol. 18. No.1, Maret 2021 : 1-9

EISSN : $2442-9813$

ISSN : $1829-9822$

harta tertentu, jenis harta tertentu untuk orang-orang tertentuyang dijelaskan oleh Allah SWT dengan tujuan semata-mata mengharapkan ridho Allah SWT. (c) Ulama Syafiiah mendefenisikan zakat adalah nama yang diperuntukan bagi harta yang dikeluarkan atas tujuan tertentu dan cara tertentu pula. (d) Ulama Hanabillah mengemukakan zakat adalah hak atau kewajiban yang melekat pada harta tertentu untuk kelompokkelompok tertentu dan dikeluarkan pada waktu-waktu tertentu (M. Amin Suma, 2019).

Harta zakat perusahaan lembaga keuangan terdiri atas kas tunai dan setara kas yang tersimpan di bank juga yang ada pada bank afiliasi. Ditambah dengan pertambahan nilai investasi berdasarkan harga pasar, piutang dan akun berjalan pada pihak lain. Takaran zakat $=$ (Harta zakat - liabilitas dan kewajiban). Nishab zakat lembaga keuangan syariah setara 85 gram emas murni dengan persentase 2,5\% (PUSKAS BAZNAS, 2018).

\section{METODE PENELITIAN}

Penelitian ini menggunakan metode deskriptif, populasi dalam penelitian ini terdiri dari 14 (empat belas) Bank Umum Syariah (BUS) yang ada di Indonesia dan menggunakan total sampling yaitu: Bank Aceh Syariah, Bank Muamalat Indonesia, Bank Victoria Syariah, Bank BRI Syariah, Bank Jabar Banten Syariah, Bank BNI Syariah, Bank Syariah Mandiri, Bank Mega Syariah, Bank Panin Syariah, Bank Syariah Bukopin, BCA Syariah, Maybank Syariah, BTPN Syariah dan Bank NTB Syariah. Data yang digunakan terdiri data primer dan sekunder. Data primer diperoleh dari deep interview dengan pihak DSN-MUI dan pihak perbankan syariah, data sekunder berupa laporan keuangan sumber dan alokasi dana zakat BUS yang diperoleh dari laman resmi web
Otoritas Jasa Keuangan (OJK) kemudian di analisa dengan metode deskriptif.

\section{HASIL DAN PEMBAHASAN}

Implementasi Pengelolaan dana zakat pada Bank Umum Syariah (BUS) di Indonesia. (a) Penghimpunan Dana Zakat Pada Perbankan Syariah. Berdasarkan laporan pengelolaan zakat yang dikeluarkan oleh Bank Umum Syariah (BUS) per Desember 2018 diperoleh data sebagai berikut;

Pengelolaan dan Penerimaan Zakat pada Bank Umum Syariah (Dalam Jutaan Rupiah)

\begin{tabular}{|c|c|c|c|c|c|c|}
\hline \multirow{2}{*}{ No. } & \multirow{2}{*}{ Nama BUS } & \multicolumn{2}{|c|}{ Pengelolaan Dana Zakat } & \multirow{2}{*}{\begin{tabular}{|l} 
Lembaga zakat yang \\
dibentuk oleh BUS
\end{tabular}} & \multicolumn{2}{|c|}{ Jumlah Penerimaan Zakat } \\
\hline & & \begin{tabular}{|l|} 
Sendiri \\
\end{tabular} & Pihak Lain & & 2017 & 2018 \\
\hline 1 & Bank Aceh Syariah & $\sqrt{ }$ & & & $4,709.14$ & 10,020 \\
\hline 2 & Bank Muamalat Indonesia & & $\sqrt{ }$ & $\begin{array}{l}\text { Yayasan Baitul Mal } \\
\text { Muamalat }\end{array}$ & 15,150 & 10,586 \\
\hline 3 & Bank Victoria Syariah & & $\checkmark$ & $\begin{array}{l}\text { UPZ Bank Victoria } \\
\text { Syariah }\end{array}$ & 32.58 & 28.66 \\
\hline 4 & Bank BRISyariah & & $\sqrt{v}$ & UPZ BRI Syariah & 8,799 & 7,192 \\
\hline 5 & Bank Jabar Banten Syariah & $\sqrt{ }$ & & & 199 & 206 \\
\hline 6 & Bank BNI Syariah & & $\sqrt{ }$ & UPZ BNI Syariah & 19,299 & 23,927 \\
\hline 7 & Bank Syariah Mandiri & & $\sqrt{ }$ & Laznas BSM Umat & 26,029 & 35,326 \\
\hline 8 & Bank Mega Syariah & $\sqrt{ }$ & & & $2,472.26$ & 1,557 \\
\hline 9 & Bank Panin Dubai Syariah & $\sqrt{ }$ & & & - & - \\
\hline 10 & BCA Syariah & $\sqrt{ }$ & & & 55.89 & 68 \\
\hline 11 & Bank BTPN Syariah & $\sqrt{ }$ & & & - & - \\
\hline 12 & Bank Syariah Buko & $\sqrt{ }$ & & & - & - \\
\hline 13 & Maybank Syariah Indonesia & $\sqrt{ }$ & & & - & - \\
\hline 14 & Bank NTB Syariah & $\sqrt{ }$ & & & & \\
\hline & & Total & & & 76,746 & 88,914 \\
\hline
\end{tabular}

Berdasarkan data dari tabel 1 di atas dapat dijelaskan bahwa, dari 14 Bank Umum Syariah (BUS) yang ada di Indonesia hanya 10 BUS yang menjalankan penghimpunan zakat, sementara 4 BUS belum melakukan pengumpulan dana zakat. Sepuluh BUS yang telah melakukan pengumpulan dan penyaluran zakat diantaranya; Bank Aceh Syariah, Bank Muamalat Indonesia, Bank Victoria Syariah, Bank BRISyariah, Bank BNI Syariah, Bank Syariah Mandiri, Bank BJB Syariah, Bank Mega Syariah, BCA Syariah, dan Bank NTB Syariah. Sedangkan 4 BUS yang belum melakukan pengelolaan zakat diantaranya; Bank BTPN Syariah, Bank Bukopin Syariah, Bank Panin Dubai Syariah, dan MayBank Syariah Indonesia.

Selanjutnya dari segi besaran dana zakat yang berhasil dihimpun, pada tahun 2017 bank syariah mengumpulkan dana zakat sebesar Rp. 76,7 Miliyar atau 1,23\% dari jumlah keseluruhan dana yang 
dihimpun oleh BAZNAS dan LAZ. Pada tahun 2018 penghimpunan dana zakat melalui BUS mengalami peningkatan sebesar $16 \%$ dari tahun 2017 atau terhimpun sebesar Rp. 88,9 Miliyar yaitu 1,1\% dari jumlah keseluruhan dana zakat yang dihimpun oleh BAZNAS dan LAZ. Jika dibandingkan besaran pengumpulan dana zakat yang dihimpun oleh BUS ini dengan potensi zakat nasional yang berjumlah Rp. 217 Triliyun, tentu capaiannya tidak sampai $1 \%$, ini artinya pengumpulan dana zakat yang dilakukan BUS masih jauh dari harapan. Padahal potensi BUS dalam pengumpulan zakat sangat luar biasa besar, apalagi potensi ini dipadukan dengan 20 Unit Usaha Syariah (UUS) dan 164 Bank Pembiayaan Rakyat Syariah (BPRS) yang ada di Indonesia.

Berdasarkan tabel 1 di atas dapat diketahui bahwa pengelolaan zakat yang dilakukan oleh bank syariah menggunakan 3 model yaitu: (1) Membentuk yayasan sendiri untuk menghimpun dan menyalurkan dana zakat, diterapkan oleh Bank Muamalat Indonesia melalui yayasan Baitul Mal Muamalat dan Bank Syariah Mandiri melalui yayasan LAZNAS BSM Umat. (2) Mengurus izin Unit Pengumpul Zakat (UPZ), kemudian disalurkan ke Badan Amil Zakat Nasional (BAZNAS) atau Lembaga Amil Zakat (LAZ), diterapkan oleh Bank Victoria Syariah, Bank BRI Syariah dan Bank BNI Syariah. (3) Menghimpun dana zakat tanpa yayasan atau UPZ kemudian menyalurkannya bersama LAZ, diterapkan oleh Bank Aceh Syariah, Bank Jabar Banten Syariah, Bank Mega Syariah, Bank BCA Syariah dan Bank NTB Syariah.

Berdasarkan tabel di atas dapat juga diketahui bahwa masih ada BUS yang belum mengelola zakat (laporan keuangan ZISWAF belum tersedia di web OJK) yaitu: Bank Panin Dubai Syariah, Bank BTPN Syariah, Bank Syariah Bukopin dan Maybank Syariah Indonesia.
Dana eksternal yang dimaksud adalah sumber dana zakat, infak dan sedekah yang berasal dari luar bank syariah, misalnya zakat, infak dan sedekah dari nasabah, rekanan, dan lain sebagainya. Pengumpulan zakat, infak dan sedekah dari nasabah dilakukan dengan cara pemotongan dari simpanan nasabah dalam bentuk giro, tabungan dan deposito berjangka yang telah sampai nisabnya dan atas persetujuan atau permintaan nasabah sendiri pada saat pembukaan rekening. Sedangkan dana infak yang dihimpun bank syariah dilakukan dengan pemanfaatan jaringan internet banking atau ATM yang tersedia dengan membuka vitur untuk menyalurkan infak dan sedekah. Adapun besaran dana zakat, infak dan sedekah yang berhasil terhimpun lewat bank syariah adalah sebagai berikut :

Jumlah Pengumpulan Zakat, Infak dan Sedekah dari Eksternal Bank Syariah (Dalam Jutaan Rupiah)

\begin{tabular}{|r|l|r|r|}
\hline \multirow{2}{*}{ No } & \multicolumn{1}{|c|}{ Nama BUS } & \multicolumn{2}{|c|}{ Penerimaan Zakat dari Eksternal } \\
\cline { 3 - 4 } & & $\mathbf{2 0 1 7}$ & $\mathbf{2 0 1 8}$ \\
\hline 1 & Bank Aceh Syariah & 4,709 & 10,020 \\
\hline 2 & Bank Muamalat Indonesia & 13,137 & 9,933 \\
\hline 3 & Bank Victoria Syariah & 0.22 & 0.03 \\
\hline 4 & Bank BRISyariah & 24 & 162 \\
\hline 5 & Bank Jabar Banten Syariah & 9 & 206 \\
\hline 6 & Bank BNI Syariah & 9,054 & 10,070 \\
\hline 7 & Bank Syariah Mandiri & 13,541 & 14,410 \\
\hline 8 & Bank Mega Syariah & - & - \\
\hline 9 & BCA Syariah & 56 & 68 \\
\hline 10 & Bank NTB Syariah & - & 3 \\
\hline \multicolumn{2}{|c|}{ Total } & $\mathbf{3 5 , 8 2 1}$ & $\mathbf{3 4 , 8 5 2}$ \\
\hline
\end{tabular}

Berdasarkan tabel 3 terlihat bahwa jumlah dana zakat, infak dan sedekah yang berhasil terhimpun oleh bank syariah adalah sebesar Rp. 35.821 Miliyar pada tahun 2017 dan Rp. 34,852 Miliyar tahun 2018. Bank Umum Syariah yang menerima ZIS dari eksternal bank berjumlah 9 BUS dan 1 BUS (Bank Mega Syariah) tidak menerima dana zakat dari pihak eksternal.

Program Penyaluran dana Zakat pada Bank Umum Syariah di Indonesia. Jenis-jenis program yang dilaksanakan dalam penyaluran dana zakat adalah sebagai berikut: (1) Pemberdayaan Ekonomi, Sebagaimana diketahui bahwa salah satu tujuan adanya zakat adalah untuk 
Jurnal Ilmiah Ekonomi dan Bisnís

Vol. 18. No.1, Maret 2021 : 1-9

EISSN : $2442-9813$

ISSN : $1829-9822$

meningkatkan kesejahteraan ekonomi masyarakat khususnya umat Islam, maka mayoritas penyaluran zakat diberikan untuk mendukung kegiatan ekonomi masyarakat miskin dalam bentuk zakat produktif. Penyaluran zakat diberikan kepada kelompok-kelompok usaha ataupun individu seperti budidaya jamur, pembuatan tusuk sate dan lain sebagainya.

(2) Pendidikan, Bentuk penyaluran dana zakat yang kedua adalah membantu biaya pendidikan seperti pemberian beasiswa dan pelatihan keterampilan kerja (soft skill). Biasanya pemberian beasiswa dipilih pada sekolah-sekolah atau perguruan tinggi yang telah bekerjasama dengan bank syariah terkait. Artinya bagi siswa atau mahasiswa yang sekolahnya belum bekerja sama dengan bank syariah atau sekolah yang lokasinya jauh dari kota belum tersentuh oleh bantuan beasiswa dari bank syariah. (3) Kesehatan, Dana zakat pada bak syariah juga diberikan kepada masyarakat miskin yang membutuhkan bantuan biaya kesehatan.

(4) Dakwah dan peribadahan, Penyaluran dana zakat untuk keperluan dakwah dimaksusdkan adalah untuk memberikan syi`ar Islam serta memperkenalkan keuangan syariah kepada masyarakat muslim secara luas, kegiatan biasanya diberikan kepada para da'i dalam bentuk training. (5) Program Peduli/social, Program peduli diberikan dalam bentuk bantuan kondisional terhadap insiden tak terduga seperti kebakaran, bencana alam (gempa, banjir, gunung meletus, longsor dan lain lain).

Faktor Pendukung dan Faktor Penghambat Pengelolaan Dana Zakat pada Bank Umum Syariah (BUS) di Indonesia. Berikut ini akan diuraikan tentang faktor pendukung penghimpunan dana zakat pada BUS di Indonesia: (a) Financial Technology, kemajuan teknologi sangat berkontribusi dalam menghimpun dana zakat pada BUS di Indonesia, pesatnya perkembangan teknologi memudahkan nasabah dalam menyalurkan Zakat, Infaq dan sedekah melalui perbankan syariah. Pilihan yang tersedia terdiri dari pemotongan bagi hasil atas permintaan nasabah secara otomatis, pembayaran melalui layanan Anjungan Tunai Mandiri (ATM), dan melalui layanan fitur e-mobile banking yang tersedia di smartphone setiap individu nasabah. (b) Memiliki basis data para muzakki yang mampu berzakat. Bank syariah memiliki dan mengetahui data keuangan nasabahnya, sehingga mampu mewarkan pembayaran zakat melalui bank tersebut, berbeda dengan BAZNAS dan LAZ lainnya yang mencari dulu para muzakinya (selain lembaga yang telah bekerjasama dengan BAZNAS dan LAZ tersebut). (c) Jaringan Kantor yang luas, jaringan kantor Bank Umum syariah yang dimiliki saat ini mencapai 1.942 unit dan terletak pada posisi-posisi strategis keramaian sehingga mudah dijangkau oleh masyarakat luas. Hal ini akan sangat membantu nasabah dalam melakukan transaksi keuangan termasuk penyaluran dana Zakat, Infak dan Sedekah. Jika digabungkan dengan jaringan kantor Unit Usaha Syariah (UUS), maka total jumlah jaringan kantor bank syariah mencapai 2.331 unit. (d) Kebijakan wajib zakat bagi karyawan yang telah sampai nisab, beberapa BUS menerapkan kebijakan wajib zakat pada karyawannya yang telah mencapai nisab. Berdasarkan pada tabel 2 di atas jumlah dana zakat yang berhasil dihimpun dari internal bank pada pada tahun 2017 adalah sebesar Rp. 35,8 Miliyar dan tahun 2018 sebesar Rp. 43,9 Miliar (jumlah ini sudah termasuk zakat perusahaan). (e) Kesadaran masyarakat (nasabah) untuk berzakat, kesadaran nasabah untuk berzakat melalui dapat dilihat dari tabel 3 di atas yang menunjukkan bahwa angka yang dicapai 
tidak jauh dari jumlah perolehan dana zakat internal bank. Hal ini juga didukung oleh kebijakan pemerintah tentang zakat pengurang pajak.

Faktor penghambat yang menjadi problematika perbankan syariah dalam menghimpun dana zakat secara umum disebabkan peraturan perundangundangan yang belum sepenuhnya mendukung peran sosial perbankan syariah, sebagaimana berikut ini: (a) Pasal 4 ayat 2 UU No. 21 Tahun 2008 tentang perbankan syariah yang menyebutkan bahwa pelaksanaan peran sosial perbankan syariah bersifat pilihan dan sukarela. Kemudian setelah dana zakat terkumpul, distribusinya harus diserahkan ke BAZNAS atau LAZ. Jika bank syariah akan mengadakan kegiatan sosial terlebih dahulu mengajukan proposal ke BAZNAS. Dari $100 \%$ dana zakat yang diserahkan ke BAZNAS, bank syariah bisa mendistribusikan dana zakat tersebut sekitar 40\% - 60\% (Asep Ahmad Mujahid, 2020). Di sisi lain Dewan Syariah Nasional-Majelis Ulama Indonesia (DSN-MUI) melalui Dewan Pengawas Syariah (DPS) tidak dapat menekan perbankan syariah untuk menggiatkan penghimpunan dana zakat, yang dapat dilakukan hanya bersifat himbauan (Azharudin Latif, 2020). Hal ini menyebabkan perbankan syariah kurang bersemangat dalam menghimpun zakat. (b) Pasal 7 ayat 2 UU No. 23 Tahun 2011 tentang pengelolaan zakat yang menyebutkan bahwa dalam menjalankan tugas dan fungsinya BAZNAS dapat bekerjasama dengan pihak terkait sesuai peraturan perundang-undangan. Dalam penjelasan pasal 7 ayat 2 tersebut menyebutkan bahwa yang dimaksud pihak terkait adalah kementrian, Badan Usaha Milik Negara (BUMN), atau lembaga luar negeri. Berdasarkan penjelasan tersebut tidak menyebutkan bank syariah sebagai salah satu mitra BAZNAS dalam menghimpun atau mengelola zakat (PPID BAZNAS, 2019). Menurut pemerintah, perbankan syariah termasuk bagian dari BUMN, namun dari 14 BUS yang ada saat ini hanya 6 bank syariah yang termasuk anak perusahaan BUMN, artinya masih ada 8 BUS yang belum terakomodir dalam UU No.23 Tahun 2011 tentang pengelolaan zakat. (c) Pasal 15b UU No. 25 Tahun 2007 tentang kewajiban perusahaan untuk menyediakan dana tanggung jawab sosial perusahaan atau yang biasa disebut Corporate Social Responsibility (CSR). Berdasarkan undang-undang ini, maka bank syariah sebagai lembaga bisnis wajib melaksanakan CSR, disisi lain bank syariah juga terpanggil untuk melaksanakan peran sosialnya. Berdasarkan kondisi ini maka perbankan syariah lebih memprioritaskan kewajiban kegiatan CSRnya di banding dengan fungsi sosial yang bersifat pilihan dan sukarela. Walaupun berdasarkan penelitian terdahulu dana CSR tersebut bersumber dana Zakat, Infak dan Sedekah atau dana sosial lainnya yang diperoleh dari nasabah (Astrid Maharani, 2016) .

\section{KESIMPULAN DAN SARAN}

Berdasarkan pembahasan di atas dapat disimpulkan bahwa implementasi pengelolaan dana zakat pada BUS belum terlaksana secara maksimal, hal ini dapat diketahui dari implementasi pengelolaan yang beragam yaitu (1) Medirikan yayasan sendiri untuk menghimpun dan menyalurkan dana zakat secara mandiri, (2) Mengurus izin Unit Pengumpul Zakat (UPZ), kemudian disalurkan ke Badan Amil Zakat Nasional (BAZNAS) atau Lembaga Amil Zakat (LAZ), (3) Menghimpun dana zakat tanpa yayasan atau UPZ kemudian menyalurkannya bersama LAZ, (4) Belum mengelola zakat. Dana zakat di distribusikan pada bidang pemberdayaan ekonomi, pendidikan, kesehatan, peribadahan atau dakwah dan 


\section{Jurnal Ilmiah Ekonomí dan Bísnis}

Vol. 18. No.1, Maret 2021 : 1-9

EISSN : $2442-9813$

ISSN : $1829-9822$

kegiatan sosial.

Faktor pendukung pengelolaan dana zakat pada BUS di Indonesia adalah (1) Kemajuan teknologi melalui Financial Technology yang memudahkan nasabah membayar zakatnya kapanpun dan dimanapun, (2) Memiliki basis data para muzaki, (3) Jaringan kantor yang luas, saat ini jumlah jaringan kantor BUS mencapai 1.942 unit, (4) Kebijakan internal bank yang mewajibkan karyawannya berzakat, dan (5) kesadaran masyarakat untuk berzakat. Faktor penghambat pengelolaan dana zakat pada BUS di Indonesia adalah ketidakpastian hukum antara pasal 4 ayat 2 UU No. 21 Tahun 2008 dengan pasal 7 ayat 2 UU No. 23 Tahun 2011, dan tumpang tindih fungsi sosial dengan kewajiban CSR perbankan syariah berdasarkan pasal 15 b UU No. 25 Tahun 2007.

\section{DAFTAR PUSTAKA}

Ahmad Dakhoir, Hukum Zakat; Pengaturan Integrasi Kelembagaan Pengelola Zakat Dengan Fungsi Lembaga Perbankan Syariah. Surabaya: Aswaja Presindo, cet. I, 2015

Ahmad Dukhoir, Bank Zakat (Gagasan, Tatanan dan Penerapan Pengelolaan Zakat Terintegritas), Jurnal AlManahij Vol. IX, No.1 Juni 2015

Aristoni, Problematika Peran Perbankan Syariah Dalam Regulasi Kelembagaan Pengelolaan Zakat, Jurnal Ziswaf, Vol. 5, No. 1, Juni 2018.

Admin Website Otoritas Jasa Keuangan (OJK) RI, Statistik Perbankan Syariah, Mei 2019, https://www.ojk.go.id/id/kanal /syariah/data-danstatistik/statistik-perbankansyariah/Pages/StatistikPerbankan-Syariah---mei- 2019.aspx, download tanggal 16 Oktober 2019.

Admin Website Otoritas Jasa Keuangan (OJK) RI, Laporan Keuangan Perbankan Syariah, https://www.ojk.go.id/id/kanal/ perbankan/data-danstatistik/laporan-keuanganperbankan/Default.aspx, diakses pada Hari Selasa, 10 Juni 2020 Pukul 09.15 WIB

Admin Website Berita Satu, UU Zakat Timbulkan Ketidakpastian Hukum Pengelolaan Zakat di Indonesia,

https://www.beritasatu.com/nasi onal/126727/uu-zakattimbulkan-ketidakpastianhukum-pengelolaan-zakat-diindonesia, diakses pada Hari Minggu, 6 Maret 2020 Pukul 23.00 WIB

Indah Purbasari, dkk, Alokasi, Distribusi Zakat dan Dana Tanggung Jawab Sosial di Perbankan Syariah dalam Masalahmasalah Hukum, Jilid 44 No.2 April 2015

Kasmir, Dasar-Dasar Perbankan, Jakarta: Raja Grafindo Persada, 2005

Kamus Besar Bahasa Indonesia (KBBI), Pengertian Rekonstruksi, https://kbbi.web.id/rekonstruksi, diakses pada Hari Jum'at, 14 Februari 2020

Muhammad Amin Suma, Sinergi Fikih dan Hukum Zakat Dari Zaman Klasik Hingga Kontemporer. Ciputat: Kolam Publising, cet. 1, 2019

Muhammad Ridwan dan Mas'ud. Zakat dan Kemiskinan Instrumen Pemberdayaan Ekonomi Umat, Yogyakarta: UII Press, 2005

Muhammad Amin Suma, Zakat, Infak dan Sedekah; Modal dan Model Ideal Pembangunan Ekonomi dan Keuangan Modern, Jurnal 
Al-Iqtishad, Vol.V, No.2 Juli 2013

Nikmatul Masruroh, Zakat di Perbankan Syariah, Jurnal al-Mashraf, Vol.2, No.1 Oktober 2015

Nurnasrina dan P. Adiyes Putra, Kegiatan Usaha Bank Syariah, Jogyakarta, Kalimedia, Cet.2, 2017

Oni Syahroni dkk., Fikih Zakat Kontemporer, Depok: Rajawali Press, 2018

Sayyid Sabiq, Fiqh al-Sunnah, jil.1, Beirut: Darul Kutub, 1973, t.th.

-, Fiqih Sunnah, Juz 3, Beirut: Darul Kutub, 1973, t.th.

Undang-Undang (UU) No. 10 Tahun 1998 tentang Perubahan Undangundang No.7 Tahun 1992 tentang Perbankan

Undang-Undang (UU) No. 7 Tahun 1992 tentang Perbankan

Undang-Undang (UU) No. 21 Tahun 2008 tentang Perbankan Syariah

Undang-Undang (UU) No. 23 Tahun 2011 tentang Pengelolaan Zakat,

Undang-Undang (UU) No. 25 Tahun 2007 tentang Penanaman Modal

Wahbah al-Zuhayli, al-Fiqhu al-Islam wa Adillatuhu Juz II, Damaskus: Dar al-Fikr, 1996

Wiroso, Produk Perbankan Syariah. Jakarta: LPFE Usakti, 2009

Yusuf Qardhawi, Kiat sukses Mengelola Zakat. Jakarta: Media Dakwah, 1997 